\title{
PENGARUH PRAKTEK KEPEMIMPINAN, PENGEMBANGAN PEGAWAI DAN PERSEPSI PERAN TERHADAP KINERJA PENYIDIK PPNS HAK KEKAYAAN INTELEKTUAL KANTOR WILAYAH DEPARTEMEN HUKUM DAN HAK ASASI MANUSIA SE-SUMATERA
}

\author{
Agustiar, Shofia Amin \& Edward \\ Fakultas Ekonomi Universitas Jambi
}

\begin{abstract}
Abstrak
Penelitian ini bertujuan untuk mengetahui pengaruh faktor-faktor kepemimpinan, pengembangan pegawai dan persepsi peran terhadap kinerja Penyidik Pejabat Pegawai Negeri Sipil Hak Kekayaan Intelektual (PPNS HKI) dan untuk mengetahui di antara faktor-faktor tersebut yang dominan berpengaruh terhadap kinerja Penyidik PPNS HKI Kantor Wilayah Departemen Hukum dan HAM Provinsi Se-Sumatera.

Populasi pada penelitian ini adalah seluruh PPNS HKI yang berada pada Provinsi Se-Sumatera sebanyak 33 orang, namun karena yang mengembalikan kuesioner hanya 30 orang, maka responden pada penelitian ini berjumlah 30 orang. Model analisis yang digunakan adalah regresi linear berganda.

Hasil penelitian menunjukkan bahwa faktor kepemimpinan, pengembangan pegawai dan persepsi peran secara simultan berpengaruh signifikan terhadap kinerja Penyidik PPNS HKI sebesar 72,10\% sedangkan sisanya sebesar 27,90\% dipengaruhi oleh variabel lain yang tidak termasuk dalam penelitian ini. Secara parsial masing-masing faktor kepemimpinan berpengaruh signifikan sebesar 24,40\%, pengembangan pegawai signifikan sebesar 26,01\% sedangkan persepsi peran secara parsial tidak signifikan karena pengaruhnya sangat kecil, hanya sebesar 1,74\% pada taraf nyata 5\%. Dengan demikian pengembangan pegawai berpengaruh dominan terhadap kinerja Penyidik PPNS HKI Kantor Wilayah Dep. Hukum dan HAM Provinsi Se-Sumatera.
\end{abstract}

Kata Kunci: Kinerja, praktek kepemimpinan, pengembangan dan persepsi peran.

PENDAHULUAN

Kinerja didefinisikan sebagai perilaku-perilaku atau tindakan-tindakan yang relevan dengan tujuan dari organisasi (McCloy, Campbell, dan Cudeck, 1994: 493). Kinerja bukan akibat, konsekuen, atau hasil dari perilaku atau tindakan, kinerja adalah tindakan itu sendiri. Kinerja pegawai sedikitnya dipengaruhi oleh dua faktor penting yang tidak dapat dipisahkan satu dengan lainnya, yakni motivasi dan kemampuan (Albanese, 1978:216). Mitchel (1985:17) menegaskan bahwa faktor motivasi dan kemampuan harus hadir untuk terjadinya kinerja yang baik. Kemampuan tanpa motivasi atau motivasi tanpa kemampuan tidak mungkin menghasilkan kinerja tinggi. Kemampunan dapat ditingkatkan melalui pengembangan pegawai dan motivasi harus selalu diberikan dalam praktek kepemimpinan.

Dalam kasus pertama, pegawai tahu apa yang akan dikerjakan tetapi tidak peduli, dan dalam kasus kedua pegawai bekerja keras tetapi tidak memiliki ketrampilan. Albanese (1978: 219) menambahkan aspek penting lainnya yang mempengaruhi kinerja yakni persepsi peran dan faktor situasional. Menurutnya, faktor motivasi 
adalah penting karena ia merupakan aspek yang membuat pegawai mau bekerja, faktor kemampuan juga penting karena ia merupakan aspek yang membuat pegawai dapat atau mampu bekerja, dan persepsi peran juga penting karena merupakan aspek yang membuat pegawai tahu mengenai apa yang akan dikerjakan, sedangkan faktor situasional seperti ketersediaan peralatan dan prasarana yang dapat diberikan oleh pimpinan juga tidak kalah pentingnya karena dapat mendukung kemampuan, motivasi dan persepsi peran.

Sebagai instansi Vertical di Provinsi yang mempunyai kewenangan dalam penegakan hukum di bidang kekayaan intelektual, maka peran Penyidik Pejabat Pegawai Negeri Sipil Hak Kekayaan Intelektual (Penyidik PPNS HKI) sangat menentukan dalam menangani tindak pidana HKI. Memperhatikan luas wilayah kerja masing-masing Provinsi, dengan keterbatasan dan tidak meratanya penempatan Penyidik PPNS HKI, serta semakin kompleknya perkara dalam wilayah operasinya, maka dengan keterbatasan tenaga merupakan tantangan berat bagi para penyidik untuk menunjukkan kinerja secara efektif.

Fakta di masyarakat menunjukkan banyaknya beredar kaset, CD, VCD dan DVD bajakan di toko-toko, swalayan bahkan pada emperan toko pun diperjualbelikan dengan bebas, baik lagu maupun film, penggandaan buku, program komputer dan pemalsuan merek. Lebih luas lagi berdasarkan laporan dari Motion Picture Association (MPA) perwakilan Film Amerika di Indonesia menyebutkan bahwa Pembajakan Film Amerika di Indonesia sudah mencapai angka 89\%, sedangkan laporan dari Business Software Alliance (BSA) yang menangani Assosiasi Software Amerika di bidang Program Komputer menyebutkan bahwa pembajakan Program Komputer di Indonesia tahun 2004 menduduki angka 88\%, dan selanjutnya atas dasar laporan United States Trade Representative (USTR) Kantor Perwakilan Dagang Amerika Serikat menyebutkan bahwa Indonesia sejak tahun 2001 sampai sekarang berada dalam daftar "Priority Watch List" maksudnya Indonesia termasuk Daftar Negara yang tidak serius dalam membantu perlindungan hukum terhadap produk-produk Amerika Serikat di Indonesia. Adapun konsekwensinya, jika tidak ada perubahan dalam kurun waktu tertentu, maka posisi tersebut akan dapat berubah menjadi "Hit List" maksudnya negara dalam daftar yang akan diberi sanksi dagang, berupa kuota ekspor, pemberhentian impor atau pencabutan sebagai negara yang mendapatkan bantuan dalam "Generalized System of Preference".

Dengan pesatnya kemajuan teknologi, secara awam sulit untuk membedakan, kecuali oleh tenaga-tenaga terampil Penyidik PPNS yang benar-benar ahli dan dapat mengetahuinya melalui proses pemeriksaan. Dampaknya adalah mengakibatkan masyarakat baik selaku pencipta maupun pemegang hak cipta dirugikan, demikian juga halnya masyarakat selaku konsumen dengan terangterangan merasa tertipu dan dirugikan, bahkan negarapun mengalami tidak sedikit kerugian dari sektor pajak, baik pajak penghasilan maupun pajak penjualan. Lebih luas lagi berdampak negatif terhadap perkembangan industri perdagangan dan 
menimbulkan persaingan bisnis yang tidak sehat baik secara nasional maupun provinsi Se-Sumatera khususnya.

Atas dasar telaahan tersebut, maka menarik dan relevan untuk dilakukan sebuah kajian mengenai upaya perbaikan kinerja. Diantara aspek-aspek penting yang perlu mendapatkan penekanan dalam upaya perbaikan kinerja adalah praktek kepemimpinan, persepsi peran dan pengembangan pegawai. Yang menjadi permasalahan dalam penelitian ini adalah:

- Apakah faktor-faktor praktek kepemimpinan, pengembangan pegawai dan persepsi peran berpengaruh terhadap kinerja penyidik PPNS HKI Kantor Wilayah Departemen Hukum dan HAM Provinsi Se-Sumatera?

- Dari faktor-faktor praktek kepemimpinan, pengembangan pegawai dan persepsi peran tersebut, faktor mana yang dominan berpengaruh terhadap kinerja penyidik PPNS HKI Kantor Wilayah Departemen Hukum dan HAM Provinsi SeSumatera?

\section{KINERJA DAN FAKTOR-FAKTOR YANG MEMPENGARUHINYA}

Ruky (2004: 14) memberikan tiga arti utama dalam menentukan definisi tentang istilah Kinerja atau prestasi guna menghilangkan kesalahpahaman dalam mendefinisikan istilah Kinerja/prestasi. Istilah kinerja/prestasi sebenarnya pengalihan bahasa dari kata Inggris "Performance", ketiga arti tersebut:

1. Adalah "prestasi" yang digunakan dalam konteks atau kalimat yang menyatakan kecepatan misalnya "mobil yang sangat cepat" ("High performance car").

2. Adalah "pertunjukan" yang biasanya digunakan dalam kalimat-kalimat petunjuk misalnya pertunjukan tari-tarian rakyat (Foldance Performance).

3. Adalah "pelaksanaan tugas" misalnya dalam kalimat sukses menyelenggarakan tugas dengan tepat waktu, tepat mutu dan tepat sasaran.

Sedangkan Lembaga Administrasi Negara dalam Sudarmayanti (2001: 50) menterjemahkan Performance menjadi Kinerja, yang juga berarti prestasi kerja, pencapaian kerja atau hasil kerja/unjuk kerja/penampilan kerja. Jadi Kinerja (Performance) adalah kemampuan setiap pegawai guna menghasilkan prestasi kerja yang unggul dalam bidang tugas masing-masing.

Mangkunegara (2002: 68) mengatakan bahwa faktor-faktor yang mempengaruhi kinerja adalah Kemampuan dan Motivasi. Kemampuan terdiri atas kemampuan potensi (IQ) dan kemampuan realitas (pengetahuan + ketrampilan) maksudnya adalah IQ pegawai diatas rata-rata dengan 110-120 dengan pendidikan yang memadai untuk jabatan, dan terampil dalam mengerjakan pekerjaan sehari-hari, maka pegawai tersebut perlu ditempatkan pada pekerjaan yang sesuai dengan keahliannya, karena ia akan lebih mudah mencapai kinerja yang diharapkan. Motivasi dimaksudkan disini terbentuk dari sikap seorang pegawai dalam menghadapi situasi kerja sebagai kondisi yang menggerakkan diri pegawai yang terarah untuk mencapai 
tujuan organisasi. Sikap mental merupakan kondisi mental yang mendorong diri pegawai untuk berusaha mencapai prestasi kerja secara maksimal atau psikofisik artinya, seorang pegawai harus siap mental, mampu secara fisik, memahami tujuan utama dan target kerja yang akan dicapai, mampu memanfaatkan dan menciptakan situasi kerja.

Demikian halnya Mahmudi (2005: 21) menyebutkan bahwa faktor-faktor yang mempengaruhi kinerja merupakan salah satu konstruk multidimensional yang mencakup banyak faktor yang mempengaruhi sebagai berikut:

- Faktor personal/individual meliputi; pengetahuan, keterampilan, kemampuan, kepercayaan diri, motivasi, dan komitmen yang dimiliki oleh setiap individu.

- Faktor kepemimpinan, meliputi; kualitas dalam memberikan dorongan, semangat, arahan, dan dukungan yang diberikan, manajer dan team leader.

- Faktor Tim, meliputi; kualitas dukungan dan semangat yang diberikan oleh rekan dalam satu tim, kepercayaan terhadap sesama anggota tim, kekompakan dan keeratan anggota tim.

- Faktor sistem, meliputi; sistem kerja, fasilitas kerja atau infrastruktur yang diberikan oleh organisasi, proses organisasi, dan kultur kinerja dalam organisasi.

- Faktor kontekstual (situasional), meliputi; tekanan dan perubahan lingkungan eksternal dan internal.

Gambar 1: Suatu Kerangka pikir secara umum tentang kinerja.

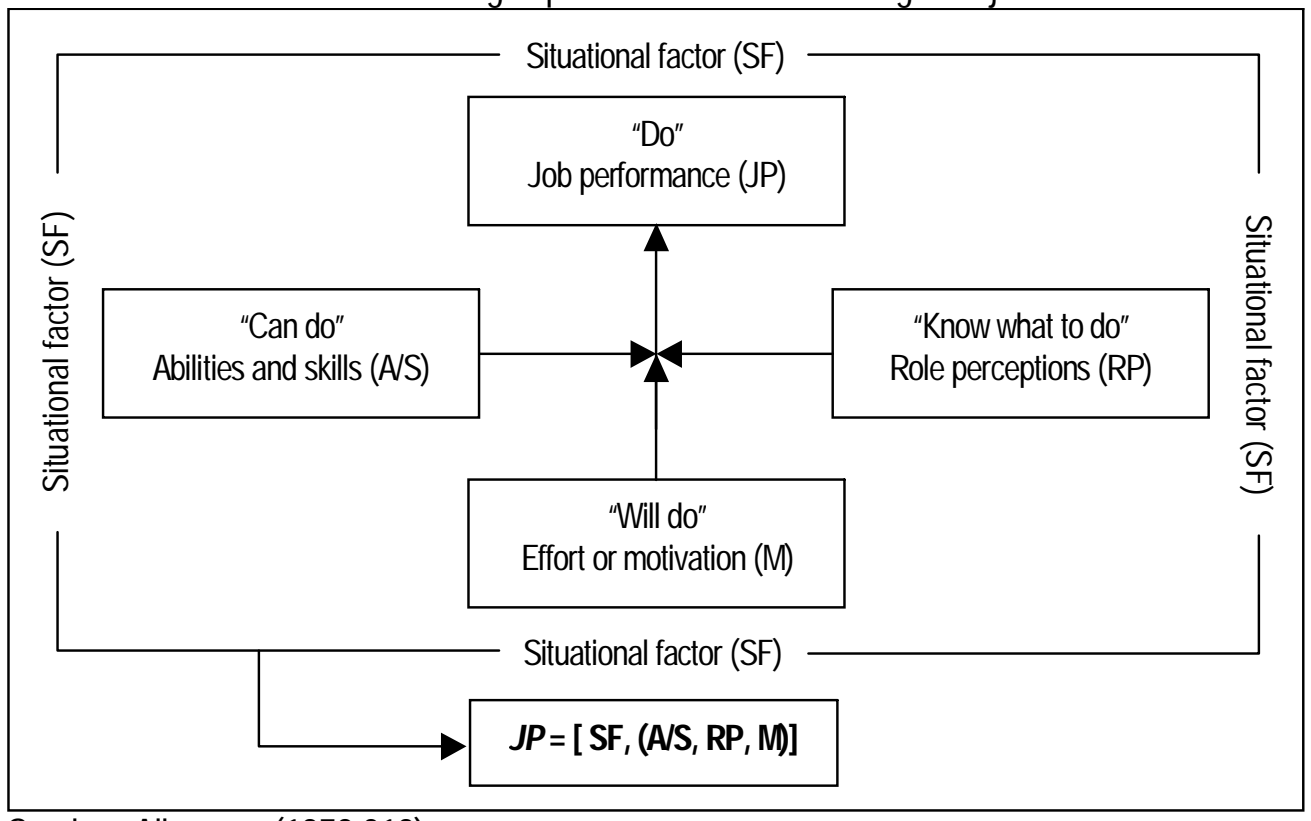

Sumber: Albanese (1978:219). 
Albanese (1978: 219) mengidentifikasi empat jenis variabel yang berbeda dan mempengaruhi kinerja seseorang yaitu situasional faktor, persepsi peran, kemampuan dan keterampilan, dan usaha atau motivasi. Dari penjelasan berbagai pendapat tentang faktor-faktor yang mempengaruhi kinerja tersebut, maka yang dijadikan landasan teori tentang faktor yang mempengaruhi kinerja dalam penelitian ini adalah praktek kepemimpinan, pengembangan pegawai dan persepsi peran.

\section{Hubungan Praktek Kepemimpinand dengan Kinerja.}

Kajian empirik dari Shoemaker (1999:2) menunjukkan bahwa lima praktek kepemimpinan yang dikonsepsikan oleh Kouzes dan Posner berhubungan dengan persepsi peran dan kepuasan kerja dari para pegawai. Kelima praktek kepemimpinan yang dikemukakan oleh Kouzes dan Posner adalah:

- Menantang Proses (Challenging the process), praktek ini melibatkan; a) mencari solusi-solusi baru terhadap masalah-masalah, mencari kesempatan-kesempatan. b) mendorong inovasi.

- Menginspirasikan sebuah visi bersama (Inspiring a shared vision), praktek ini melibatkan; a) Menciptakan dan mengkomunikasikan sebuah visi mendatang. b) Menyertakan orang lain untuk berbagi visi tersebut.

- Memberdayakan orang lain untuk bertindak (Enabling another to act), praktek ini melibatkan; a) Membangun kolaborasi dan kerjasama di dalam sebuah kelompok. b) Memperkuat kemampuan orang lain untuk berkinerja.

- Memodelkan cara atau memberi contoh (Modelling the way), praktek ini melibatkan; a) Menetapkan sebuah contoh, berperilaku dalam cara-cara yang konsisten dengan nilai-nilai yang ditetapkan. b) Merencanakan kesuksesan kecil, memungkinkan para pengikut mengalami kesuksesan nyata.

- Mendorong semangat (Encouraged the heart), praktek ini melibatkan; a) Mengakui kontribusi-kontribusi, mengkomunikasikan pengharapan-pengharapan, menampung, dan mengkaitkan kinerja dengan imbalan-imbalan. b) Merayakan keberhasilan.

Kajian Kouzes dan Posner (1987:281) memberikan bukti empirik dengan mengungkapkan bahwa bila para pemimpin menggunakan kelima praktek tersebut secara konsisten, mereka dilihat oleh orang lain yang; 1) memiliki derajat kredibilitas pribadi yang lebih tinggi, 2) lebih efektif dalam memenuhi tuntutan-tuntutan yang berkaitan dengan jabatan, 3) lebih berhasil dalam mewakili unit-unit mereka pada manajemen level atas, dan 4) memiliki tim-tim yang berkinerja tinggi.

\section{Hubungan Pengembangan Pegawai dengan Kinerja.}

Pelatihan didefinisikan sebagai sebuah proses sistematis untuk merubah perilaku, pengetahuan, dan motivasi diri pegawai guna meningkatkan kecocokan antara karakteristik pegawai dan tuntutan-tuntutan atau persyaratan-persyaratan kepegawaian (Milkovich dan Boudreau, 1991:407). Pelatihan juga merupakan bentuk pemberian instruksi untuk mengembangkan keterampilan yang dapat digunakan secara langsung pada pekerjaan (Anthony, Parrewe dan Kacmar, 1996: 319). 
Menurut Mitchel (1985: 450) pelatihan pada dasarnya adalah pembelajaran. Organisasi berupaya untuk memberikan pengalaman-pengalaman yang akan membantu untuk berkinerja secara lebih efektif pada pekerjaan. Sebuah program pelatihan dimaksudkan untuk menstruktur pengalaman-pengalaman tersebut sedemikian rupa sehingga sikap atau keterampilan yang tepat diperoleh dan dikembangkan. Jadi, pelatihan dapat dilihat sebagai sebuah upaya oleh organisasi untuk merubah perilaku para anggotanya melalui proses pembelajaran guna meningkatkan efektivitas.

Rivai (2004: 240) merinci faktor-faktor yang perlu diperhatikan serta perannya dalam pengembangan sumberdaya manusia yaitu efektivitas biaya, materi program yang dibutuhkan, prinsip-prinsip pembelajaran, ketepatan dan kesesuaian fasilitas, kemampuan dan preferensi peserta pelatihan, kemampuan dan preferensi instruktur pelatihan. Keterkaitan dan keterikatan antar faktor-faktor yang berperan dalam pelatihan dapat dilihat pada gambar 2 halaman berikut ini:

Gambar 2. Faktor-faktor yang berperan dalam pelatihan

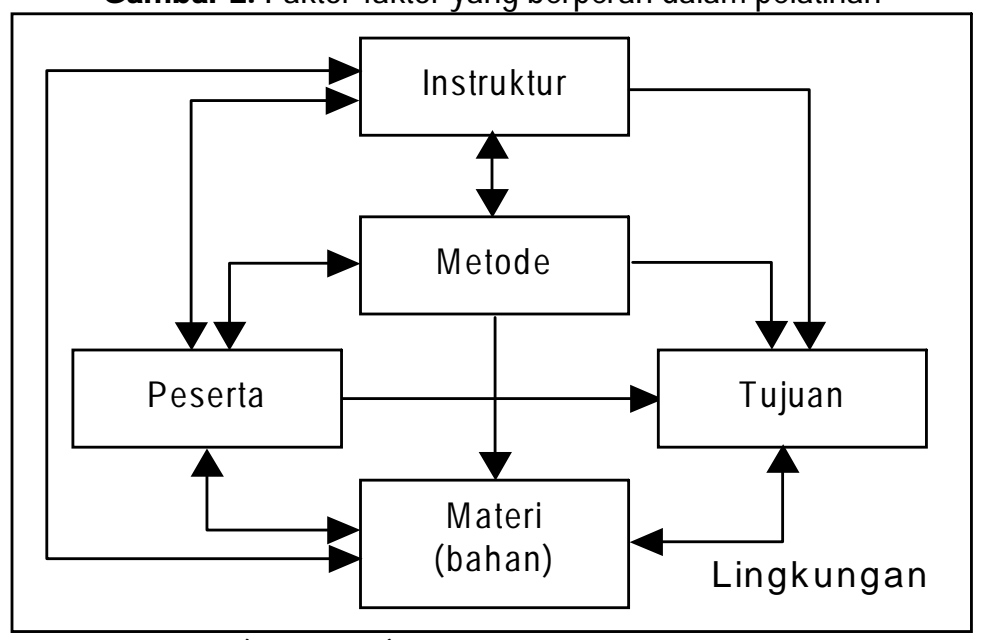

Sumber: Rivai, $(2004,240)$.

\section{Hubungan Persepsi Peran dengan Kinerja}

Albanese (1978: 223) menyebutkan bahwa Peran adalah sesuatu konsep yang bermanfaat untuk pemahaman pencapaian kinerja individu. Peran menentukan perilaku individu atau kelompok yang diharapkan dari seseorang yang menduduki suatu jabatan tertentu dalam suatu organisasi, keluarga, kelompok atau kantor, karena itu peran diharapkan untuk memberi petunjuk atau arah yang akurat untuk perilaku. Persepsi peran mengacu pada cara yang ditempuh oleh individu-individu untuk menggambarkan jenis pekerjaan yang ia percaya adalah penting guna pencapaian kinerja efektif. Persepsi peran yang ditunjukkan di sini adalah bagaimana cara melakukan bermacam-macam aktivitas dan perilaku dalam melaksanakan pekerjaan mereka. 
Mulyadi dan Johny (1999:421) menyebutkan bahwa pada umumnya yang dipromosikan ke posisi manajerial tidak memahami perannya sebagai manajer. Seorang akan menghasilkan suatu kinerja jika memiliki sekaligus ketiga komponen berikut ini; (1). Bakat dan Kemampuan (traits and abilities), (2). Motivasi untuk berusaha (efforts), dan (3). Persepsi yang jelas mengenai perannya (Clear perception with its role).

Setelah seorang dipromosikan sebagai Manajer, disamping umumnya ia tidak memiliki kompetensi manajerial, ia juga tidak memiliki persepsi yang jelas mengenai perannya sebagai manajer. Dengan demikian, dari ketiga komponen penentu kinerja tersebut, hanya motivasi untuk berusaha yang dimiliki oleh manajer. Namun apalah artinya usaha, jika tidak dilandasi dengan kompetensi dan persepsi mengenai peran. Tanpa kompetensi manajerial dan tanpa pemahaman memadai tentang perannya sebagai manajer, kondisi ini akan mengakibatkan seorang manajer melakukan banyak aktivitas namun tidak mampu menghasilkan nilai (value) bagi pemilik.

Cook dan Phillip L. Hunsaker (2001: 162) mengatakan bahwa persepsi adalah penyeleksian, pengorganisasian dan penginterprestasian data yang berhubungan dengan panca indra. Orang tidak melihat objek sebenarnya, tetapi mereka percaya apa yang mereka persepsikan adalah benar. Persepsi kita adalah realita pribadi kita, tidak peduli apakah objektif atau tidak dan persepsi akan mempengaruhi perilaku.

Lebih lanjut Cook dan Phillip L. Hunsaker (2001: 254) mengatakan bahwa ada dimensi lain dari pekerjaan yang mempengaruhi sikap pekerja dengan kemauan mereka untuk berkinerja tinggi. Dimensi tersebut berkaitan dengan dimensi inti pekerjaan, karyawan merasa kompeten dalam mengendalikan pekerjaannya, mendorong inisiatif bertahan pada tugas yang penuh arti. Kondisi ini akan berpengaruh positif terhadap persepsi diri yang dipengaruhi oleh self concept yaitu bagaimana kita berfikir tentang diri kita sendiri atau melihat diri kita dalam sebuah peran, self esteem yaitu bagaimana kita secara umum merasa berguna atau perasaan diri bahwa kita berguna, dan self efficacy yaitu persepsi kita tentang kemampuan untuk berkinerja, hal ini akan mempengaruhi peningkatan kinerja dengan membentuk 3 (tiga) kondisi psikologis.

Kondisi psikologis tersebut akan berdampak pada motivasi dan kepuasan kerja akan tetapi diawali dari persepsi tentang bagaimana pekerjaan tersebut pada masing-masing pegawai. Adapun ketiga kondisi psikologis tersebut adalah:

1. Persepsi pekerjaan penuh arti.

Aktivitas pekerjaan yang dilakukan harus memiliki sasaran yang jelas, dipersepsikan penting dan bemanfaat. Persepsi ini dipengaruhi oleh pekerjaan yang memerlukan keterampilan tinggi, identitas tugas dan signifikasi tugas.

2. Persepsi tanggung jawab.

Pegawai harus yakin bahwa secara secara pribadi mereka bertanggung jawab terhadap hasil dan usahanya akan mempengaruhi hasil. Persepsi ini dipengaruhi oleh otonomi pekerjaan. 
3. Persepsi pengetahuan akan hasil.

Pekerjaan harus mendapat informasi secara teratur dan tepat waktu tentang seberapa baik ia melaksanakan tugasnya. Persepsi ini dipengaruhi oleh umpan balik pekerjaan.

Cook dan Phillip L. Hunsaker juga mengatakan dimensi inti pekerjaan yang menyenangkan menurut persepsi pegawai akan menghasilkan motivasi potensal positif yang akan mempengaruhi hasil kinerja. Hasil kinerja tersebut diukur dengan adanya keterlibatan kerja, motivasi dan kepuasan pada tingkat pribadi dan kinerja pada tingkat pekerjaan. Manifestasi penting dari dimensi inti pekerjaan adalah kondisi yang menyenangkan.

\section{KERANGKA PEMIKIRAN}

Kajian-kajian teoritis dan temuan-temuan empirik serta rekomendasirekomendasi riset yang dikemukakan oleh para ahli akhirnya menuntun peneliti untuk mengkaji praktek kepemimpinan, pengembangan pegawai dan persepsi peran dalam hubungannya dengan kinerja Penyidik PPNS HKI pada Kantor Wilayah Departemen Hukum dan HAM Provinsi Se-Sumatera. berikut ini:

Hubungan di antara variabel-variabel tersebut ditunjukkan pada gambar 3

Gambar 3. Model Hubungan antara Praktek Kepemimpinan, Pengembangan Pegawai dan Persepsi Peran dengan Kinerja.

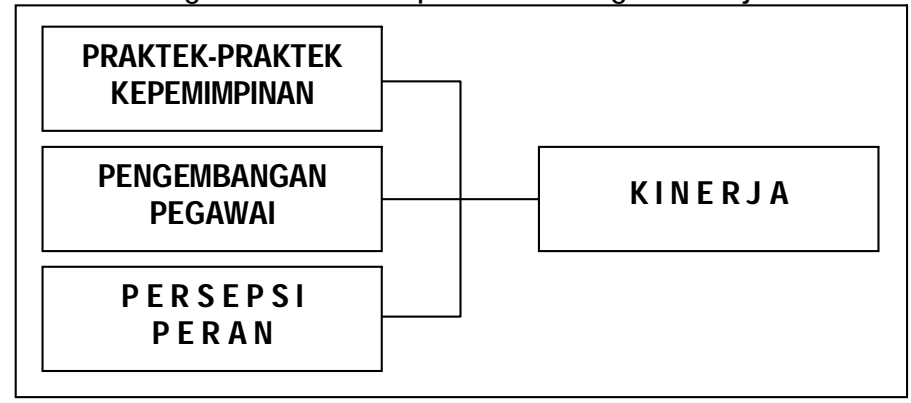

Gambar 3 tersebut memperlihatkan mekanisme hubungan diantara faktorfaktor Kepemimpinan, Pengembangan Pegawai dan Persepsi Peran dengan kinerja Penyidik PPNS HKI pada Kantor Wilayah Departemen Hukum dan Ham Provinsi SeSumatera. Hipotesis yang akan diuji kebenarannya dalam penelitian ini adalah:

1. Faktor-faktor praktek kepemimpinan, pengembangan pegawai, dan Persepsi Peran diduga berpengaruh terhadap kinerja penyidik PPNS Hak Kekayaan Intelektual Kantor Wilayah Departemen Hukum dan Hak Asasi Manusia Provinsi Se-Sumatera. 
2. Dari faktor-faktor tersebut, faktor pengembangan pegawai diduga berpengaruh dominan terhadap kinerja penyidik PPNS Hak Kekayaan Intelektual Kantor Wilayah Departemen Hukum dan Hak Asasi Manusia Provinsi Se-Sumatera.

\section{METODE PENELITIAN}

Populasi dalam penelitian ini adalah seluruh Penyidik PPNS HKI Kantor Wilayah Departemen Hukum dan HAM Provinsi Se-Sumatera ynag berjumlah 33 orang. Variabel bebas dalam penelitian ini adalah Praktek Kepemimpinan, Pengembangan Pegawai dan Persepsi Peran, sedangkan Kinerja Penyidik PPNS HKI sebagai variabel terikat (dependen). Jenis data yang digunakan adalah data primer dan skunder. Pengumpulan data dilakukan dengan metode kuesioner, wawancara dan dokumentasi. Dengan bantuan program SPSS Versi 11 dilakukan analisis data guna membuktikan hipotesis dengan menggunakan uji statistik yang didukung oleh uji Ekonometrika.

Adapun model yang digunakan dalam analisis data adalah persamaan regresi linear berganda dengan rumus:

$$
Y=b 0+b 1 X 1+b 2 X 2+b 3 X 3+e
$$

Dimana:

Y $\quad=$ Variabel Kinerja Penyidik PPNS HKI.

b0 $\quad=$ Konstanta.

b1, b2 , b3 = Koofisien Regresi.

X1 = Variabel Praktek Kepemimpinan.

X2 = Variabel Pengembangan Pegawai.

X3 $=$ Variabel Persepsi Peran.

Definisi operasional variabel yang digunakan disajikan pada Tabel 1 di bawah ini. 
Tabel 1. Defini Operasional Variabel

\begin{tabular}{|c|c|c|}
\hline $\begin{array}{c}\text { Variabell } \\
\text { Sub Variabel }\end{array}$ & $\begin{array}{c}\text { Konsep Variabell } \\
\text { Sub Variabel }\end{array}$ & Indikator \\
\hline 1 & 2 & 3 \\
\hline $\begin{array}{c}\text { Kinerja } \\
(Y)\end{array}$ & $\begin{array}{l}\text { Tindakan atau perilaku-perilaku } \\
\text { penyidik PPNS HKI Kanwil Depar- } \\
\text { temen Hukum dan HAM Provinsi } \\
\text { Se-Sumatera yang relevan sesuai } \\
\text { tugas pokok dan fungsi yang telah } \\
\text { ditentukan dalam JUKLAKI JUKNIS } \\
\text { dalam kurun waktu tertentu } 1 \text { (satu) } \\
\text { tahun terakhir yakni tahun 2004 } \\
\text { agar dapat memberi kan kontribusi } \\
\text { guna pencapaian tujuan organisasi. }\end{array}$ & $\begin{array}{l}\text { 1. Jumlah perkara yang berhasil dikerjakan penyidik PPNS HKI } \\
\text { dalam kurun waktu } 1 \text { tahun. } \\
\text { 2. Hasil penyidikan memenuhi kualitas yang standar. } \\
\text { 3. Proses penyidikan diselesaikan sesuai target waktu. } \\
\text { 4. Memiliki pengetahuan dan keterampilan dalam menjalankan } \\
\text { tugas penyidikan. } \\
\text { 5. Adanya kerjasama antar penyidik melaksanakan penyidikan. } \\
\text { 6. Adanya rasa tanggung jawab masing-masing penyidik. } \\
\text { 7. Adanya inisiatif, sikap, kreatifitas dan kemampuan dalam } \\
\text { menyelesaikan masalah yang timbul. }\end{array}$ \\
\hline $\begin{array}{c}\text { Praktek } \\
\text { Kepemimpinan } \\
\text { (X1) }\end{array}$ & $\begin{array}{l}\text { Aktivitas yang dilakukan pemimpin } \\
\text { dlm mendorong penyidik PPNS HKI } \\
\text { Kanwil Dep. Hukum dan HAM } \\
\text { Provinsi Se-Sumatera guna mening- } \\
\text { katkan kinerja. }\end{array}$ & $\begin{array}{l}\text { 1. Menantang Proses yakni: } \\
\text { a. Mencari solusi, peluang baru dan tanggap terhadap } \\
\text { perkembangan terhadap masalah yang dihadapi. } \\
\text { b. Mendorong inovasi. } \\
\text { 2. Menginspirasikan sebuah visi bersama meliputi: } \\
\text { a. Mengkomunikasikan visi masa depan. } \\
\text { b. Mengajak orang lain untuk merubah visi menjadi realita. } \\
\text { 3. Memberdayakan orang lain untuk bertindak meliputi: } \\
\text { a. Membangun kerja sama dalam kelompok. } \\
\text { b. Memperkuat orang lain untuk berkinerja dengan mem- } \\
\text { berikan wewenang. } \\
\text { 4. Memberikan contoh meliputi: } \\
\text { a. Memberikan teladan dengan berperilaku secara konsis- } \\
\text { ten sesuai dengan nilai-nilai bersama. } \\
\text { b. Mencapai kemenangan guna meningkatkan keinginan } \\
\text { yang konsisten dan membina komitmen. } \\
\text { 5. Mendorong Semangat meliputi: } \\
\text { a. Menghargai kontribusi individu terhadap keberhasilan } \\
\text { setiap pelaksanaan tugas. } \\
\text { b. Merayakan keberhasilan kinerja. }\end{array}$ \\
\hline $\begin{array}{c}\text { Pengembangan } \\
\text { Pegawai (X2) }\end{array}$ & $\begin{array}{l}\text { Reaksi para peserta Diklat terhadap } \\
\text { keberhasilan pelaksanaan Diklat } \\
\text { Penyidik PPNS HKI yang dapat } \\
\text { mempengaruhi peningkatan Kinerja. }\end{array}$ & $\begin{array}{l}\text { 1. Jumlah Diklat yang diikuti oleh penyidik PPNS HKI. } \\
\text { 2. Relevansi materi Diklat yang diikuti dengan bidang tugas } \\
\text { Penyidik PPNS HKI. } \\
\text { 3. Ketepatan metoda Diklat yang diikuti. } \\
\text { 4. Kompetensi instruktur dengan sasaran yang hendak dicapai. } \\
\text { 5. Ketersediaan fasilitas untuk meningkatkan pengetahuan dan } \\
\text { ketarampilan. } \\
\text { 6. Informasi kesempatan pengembangan terbuka bagi semua } \\
\text { 7. Penyidik PPNS HKI. } \\
\text { 8. Pengembangan mandiri. }\end{array}$ \\
\hline 1 & 2 & 3 \\
\hline $\begin{array}{l}\text { Persepsi peran } \\
\text { (X3) }\end{array}$ & $\begin{array}{l}\text { Pandangan penyidik PPNS HKI } \\
\text { tentang cara dalam bersikap dan } \\
\text { atau berprilaku terhadap suatu } \\
\text { keadaan tertentu guna pelaksanaan } \\
\text { tugas penyidikan sesuai prosedur } \\
\text { yang ditetapkan. }\end{array}$ & $\begin{array}{l}\text { 1. Memiliki persepsi bahwa penyidik PPNS HKI mempunyai } \\
\text { peran penting dalam penegakan hukum sbb: } \\
\text { a. Pekerjaan penyidik memerlukan keragaman keterampilan } \\
\text { (syarat-syarat penyidik). } \\
\text { b. Pekerjaan penyidik memiliki identitas tugas (tugas dan } \\
\text { tanggung jawab yang jelas). }\end{array}$ \\
\hline
\end{tabular}




\begin{tabular}{|l|l|l|}
\hline & $\begin{array}{l}\text { C. Pekerjaan penyidik memiliki signifikansi tugas (punya arti } \\
\text { penting). } \\
\text { d. Pekerjaan penyidik merupakan profesi yang memiliki } \\
\text { prestise tersendiri. }\end{array}$ \\
& 2. Memiliki persepsi bahwa penyidik PPNS HKI menuntut \\
pertanggung jawaban pribadi atas hasil usahanya. \\
a. Adanya otonomi Penyidik PPNS HKI dalam melak- \\
sanakan tugas. \\
b. Adanya rasa kebangaan tersendiri dalam tugas. \\
3. Memiliki persepsi bahwa penyidik PPNS HKI memiliki \\
pengetahuan akan hasil kerja. \\
a. Adanya umpan balik yang diperoleh penyidik PPNS HKI \\
terhadap kinerja yang mereka capai. \\
b. Adanya dampak psikologis terhadap perbedaan penghasi- \\
lan antara penyidik dengan yang bukan penyidik.
\end{tabular}

\section{HASIL DAN PEMBAHASAN}

\section{Deskripsi Hasil Penelitian}

Kuesioner disebarkan kepada seluruh PPNS HKI Kantor Wilayah Departemen Hukum dan HAM Provinsi se-Sumatera sebanyak 33 orang yang tersebar pada 10 Provinsi yang terdapat di Pulau Sumatera. Namun karena pada tgl 26 Desember 2004 Propinsi NAD tertimpa musibah tsunami, maka yang mengembalikan kuesioner tersebut hanya 30 orang.

Masing-masing kuesioner diberi skor 1 sampai 5 sesuai dengan skala Likert dan disediakan alternatif jawaban sangat sering, sering, kadang-kadang, tidak pernah dan sama sekali tidak pernah untuk variabel kinerja, praktek kepemimpinan dan pengembangan pegawai. Sedangkan untuk variabel persepsi peran disediakan alternatif jawaban sangat setuju, setuju, netral, tidak setuju dan sangat tidak setuju. Karena data yang terkumpul dari kuesioner berskala ordinal, maka untuk pemenuhan syarat regresi data tersebut ditranformasikan ke Z score.

Mayoritas responden adalah laki-laki (24 orang), status kawin (28 orang) dan berusia antara 40-49 tahun (12 orang), sedangkan selebihnya adalah perempuan ( 6 orang), status belum kawin (2 orang), berusia 30-39 tahun (10 orang) dan berusia 50 tahun sebanyak 8 orang. Keseluruhan responden berjumlah 30 orang. Adapun rekapitulasi hasil jawaban responden terhadap masing-masing variabel penelitian dapat dilihat selengkapnya pada tabel-tabel halaman berikut ini:

Tabel 2. Kinerja Penyidik PPNS HKI Kantor Wilayah Dep.Hukum dan HAM Provinsi Se-Sumatera $(Y)$.

\begin{tabular}{|c|c|c|c|c|c|}
\hline$\frac{\mathrm{Nttg}-\mathrm{Ntrh}}{\text { Kelas interval }}$ & No. & Interval & Kategori Kinerja & Frekuensi & $\begin{array}{c}\text { Persentase } \\
\text { (\%) }\end{array}$ \\
\hline \multirow{4}{*}{$\frac{4,75-1,75}{3}=1$} & 1. & $1,75-2,75$ & Rendah & 5 & 16,67 \\
\hline & 2. & $2,76-3,76$ & Sedang & 16 & 53,33 \\
\hline & 3. & $3,77-4,77$ & Tinggi & 9 & 30,00 \\
\hline & \multicolumn{3}{|c|}{ Total } & 30 & 100 \\
\hline
\end{tabular}

Sumber data: hasil olahan data primer. 
Tabel 3. Respon Terhadap Variabel Praktek Kepemimpinan

\begin{tabular}{|c|c|c|c|c|c|c|c|c|c|c|c|}
\hline \multirow{2}{*}{ No. } & \multirow{2}{*}{ Kategori } & \multicolumn{5}{|c|}{ Frekuensi } & \multicolumn{5}{|c|}{ Prosentase (\%) } \\
\hline & & SS & $\mathbf{s}$ & $\mathrm{K}$ & TP & STP & SS & S & $\mathrm{K}$ & TP & STP \\
\hline 1. & $\begin{array}{l}\text { Mencari kesempatan untuk } \\
\text { mengubah, meningkatkan } \\
\text { dan mengembangkan ter- } \\
\text { hadap penyelesaian peker- } \\
\text { jaan }\end{array}$ & 1 & 1 & 8 & 20 & - & 3,3 & 3,3 & 26,7 & 66,7 & - \\
\hline 2. & Mendorong Inovasi & 1 & 1 & 13 & 14 & 1 & 3,3 & 3,3 & 43,3 & 46,7 & 3,3 \\
\hline 3. & $\begin{array}{l}\text { Mengkomunikasikan visi } \\
\text { masa depan }\end{array}$ & 2 & 1 & 18 & 9 & - & 6,7 & 3,3 & 60 & 30 & - \\
\hline 4. & $\begin{array}{l}\text { Mengajak orang lain untuk } \\
\text { merubah visi menjadi realita }\end{array}$ & 1 & - & 10 & 17 & 2 & 3,3 & 0 & 33,3 & 56,7 & 6,7 \\
\hline 5. & $\begin{array}{l}\text { Membagun kerja sama } \\
\text { dalam kelompok }\end{array}$ & 1 & 4 & 12 & 13 & - & 3,3 & 13,3 & 40 & 43,3 & - \\
\hline 6. & $\begin{array}{l}\text { Memperkuat orang lain } \\
\text { untuk berkinerja. }\end{array}$ & - & 2 & 11 & 17 & - & - & 6,7 & 36,7 & 56,7 & \\
\hline 7. & $\begin{array}{l}\text { Memberikan teladan de- } \\
\text { ngan berperilaku secara } \\
\text { konsisten sesuai dengan } \\
\text { nilai bersama }\end{array}$ & 2 & 2 & 19 & 7 & - & 6,7 & 6,7 & 63,3 & 23,3 & - \\
\hline 8. & $\begin{array}{l}\text { Mencapai kemenangan } \\
\text { yang meningkatkan keingi- } \\
\text { nan yang konsisten dan } \\
\text { membina komitmen }\end{array}$ & - & 4 & 13 & 13 & - & - & 13,3 & 43,3 & 43,3 & - \\
\hline 9. & $\begin{array}{l}\text { Menghargai kontribusi indi- } \\
\text { vidu terhadap keberhasilan } \\
\text { setiap pelaksanaan tugas }\end{array}$ & 1 & 1 & 3 & 25 & - & 3,33 & 3,3 & 10 & 83,3 & - \\
\hline 10. & $\begin{array}{l}\text { Merayakan keberhasilan } \\
\text { kinerja. }\end{array}$ & - & 1 & 4 & 21 & 4 & - & 3,3 & 13,3 & 70 & 13,3 \\
\hline
\end{tabular}

Sumber data: hasil olahan data primer. 
Tabel 4. Respon Terhadap Variabel Pengembangan Pegawai

\begin{tabular}{|c|c|c|c|c|c|c|c|c|c|c|c|}
\hline \multirow{2}{*}{ No. } & \multirow{2}{*}{ Kategori } & \multicolumn{5}{|c|}{ Frekuensi } & \multicolumn{5}{|c|}{ Prosentase (\%) } \\
\hline & & SS & S & K & TP & STP & SS & $S$ & K & TP & STP \\
\hline 1. & $\begin{array}{l}\text { Materi Diklat yang diprogramkan } \\
\text { dalam proses pembelajaran } \\
\text { sangat relevan dengan bidang } \\
\text { tugas sebagai penyidik PPNS HKI }\end{array}$ & 6 & 19 & 5 & - & - & 20 & 63,3 & 16,7 & - & - \\
\hline 2. & $\begin{array}{l}\text { Metoda Diklat yang disampaikan } \\
\text { relefan dengan sasaran yang di } \\
\text { inginkan. }\end{array}$ & 2 & 10 & 18 & - & - & 6,7 & 33,3 & 60 & - & - \\
\hline 3. & $\begin{array}{l}\text { Cara penyajian tiap-tiap materi } \\
\text { bahan oleh para Instruk- } \\
\text { tur/Widiyaiswara dapat dengan } \\
\text { mudah dimengerti oleh saya } \\
\text { sebagai peserta diklat. }\end{array}$ & 2 & 23 & 5 & - & - & 6,7 & 76,7 & 16,7 & - & - \\
\hline 4. & $\begin{array}{l}\text { Para instruktur/widiyaiswara yang } \\
\text { melatih/mengajar saya pada diklat } \\
\text { rata-rata memiliki kompetensi } \\
\text { pendidikan formal dan teknis yang } \\
\text { memadai. }\end{array}$ & 3 & 14 & 11 & 2 & - & 10 & 46,7 & 36,7 & 6,7 & - \\
\hline 5. & $\begin{array}{l}\text { Ketersediaan fasilitas untuk me- } \\
\text { ningkatkan pengetahuan dan } \\
\text { keterampilan berupa perpusta- } \\
\text { kaan, SJDI Hukum dan SIMDK } \\
\text { tersedia di kantor wilayah }\end{array}$ & 5 & 10 & 13 & 2 & - & 16,7 & 33,3 & 43,3 & 6,7 & - \\
\hline 6. & $\begin{array}{l}\text { Kesempatan untuk mengikuti } \\
\text { diklat penyidik PPNS diinformasi- } \\
\text { kan terbuka bagi pegawai melalui } \\
\text { masing-masing kantor wilayah. }\end{array}$ & 2 & 7 & 14 & 7 & - & 6,7 & 23,3 & 46,7 & 23,3 & - \\
\hline 7. & $\begin{array}{l}\text { Pemilihan peserta diklat dimasing- } \\
\text { masing kantor wilayah sesuai } \\
\text { dengan bidang tugas yang dilak- } \\
\text { sanakan melalui sidang TSPD. }\end{array}$ & 1 & 8 & 19 & 2 & - & 3,3 & 26,7 & 63,3 & 6,7 & - \\
\hline 8. & $\begin{array}{l}\text { Selain pengembangan pegawai } \\
\text { yang disediakan oleh instansi, } \\
\text { saya mengikuti pengembangan } \\
\text { secara mandiri. }\end{array}$ & 3 & 9 & 5 & 12 & 1 & 10 & 30 & 16,7 & 40 & 3,3 \\
\hline 9. & $\begin{array}{l}\text { Jenis Diklat yang pernah oleh } \\
\text { Penyidik PPNS HKI sebagai } \\
\text { penunjang pelaksanaan tugas. }\end{array}$ & 25 & 2 & 3 & - & - & 83,3 & 6,7 & 10 & - & - \\
\hline
\end{tabular}

Sumber data: hasil olahan data primer. 
Tabel 5. Respon Terhadap Variabel Persepsi Peran.

\begin{tabular}{|c|c|c|c|c|c|c|c|c|c|c|c|}
\hline \multirow{2}{*}{ No. } & \multirow{2}{*}{ Kategori } & \multicolumn{5}{|c|}{ Frekuensi } & \multicolumn{5}{|c|}{ Prosentase (\%) } \\
\hline & & SS & $S$ & $\mathrm{~N}$ & TS & STS & SS & S & $\mathbf{N}$ & TS & STS \\
\hline 1. & $\begin{array}{l}\text { Persyaratan khusus untuk } \\
\text { menjadi Penyidik PPNS HKI }\end{array}$ & 8 & 18 & 1 & 3 & - & 26,7 & 60 & 3,3 & 10 & - \\
\hline 2. & $\begin{array}{l}\text { Kejelasan tugas sesuai tugas } \\
\text { pokok dan fungsi }\end{array}$ & 5 & 24 & 1 & - & - & 16,7 & 80 & 3,3 & - & - \\
\hline 3. & $\begin{array}{l}\text { Memiliki arti penting dalam } \\
\text { memberantas tindak pidana HKI }\end{array}$ & 7 & 9 & 13 & 1 & - & 23,3 & 30 & 43,3 & 3,3 & - \\
\hline 4. & $\begin{array}{l}\text { Jadi Penyidik PPNS HKI memiliki } \\
\text { kebanggaan tersendiri. }\end{array}$ & 4 & 5 & 10 & 10 & 1 & 13,3 & 16,7 & 33,3 & 33,3 & 3,3 \\
\hline 5. & $\begin{array}{l}\text { Dalam melaksanakan tugas pe- } \\
\text { nyidikan memiliki otonomi penuh. }\end{array}$ & 5 & 18 & 5 & 2 & - & 16,7 & 60 & 16,7 & 6,7 & - \\
\hline 6. & $\begin{array}{l}\text { Jadi Penyidik PPNS HKI memiliki } \\
\text { prestise tersendiri dimata } \\
\text { masyarakat. }\end{array}$ & 4 & 9 & 8 & 9 & - & 13,3 & 30 & 26,7 & 30 & - \\
\hline 7. & $\begin{array}{l}\text { Keberhasilan dalam Penyidikan } \\
\text { mendapatkan penghargaan dari } \\
\text { pimpinan. }\end{array}$ & 1 & 5 & 6 & 15 & 3 & 3,3 & 16,7 & 20 & 50 & 10 \\
\hline 8. & $\begin{array}{l}\text { Penyidik PPNS HKI memiliki } \\
\text { perbedaan pendapatan dengan } \\
\text { yang bukan penyidik }\end{array}$ & 1 & 19 & 8 & 2 & - & 3,3 & 63,3 & 26,7 & 6,7 & - \\
\hline
\end{tabular}

Sumber data: hasil olahan data primer.

\section{PEMBUKTIAN HIPOTESIS}

Uji F

Untuk mengetahui tingkat kemaknaan secara simultan semua variabel, maka digunakan Uji F seperti tampak pada Tabel 6.

Dari hasil uji $F$ menunjukkan bahwa probabilitas $0,000<0,05$ pada taraf a 0,5 atau $\mathrm{F}$ hitung sebesar 22,383> dari Ftabel 2,92. Artinya praktek kepemimpinan, pengembangan pegawai dan persepsi peran secara simultan berpengaruh signifikan terhadap kinerja Penyidik PPNS HKI pada taraf $\alpha=0,05$ atau dengan kata lain pada taraf nyata $5 \%$ hipotesis pertama diterima atau terbukti.

Untuk mengetahui besarnya pengaruh praktek kepemimpinan, pengembangan pegawai dan persepsi peran secara serentak terhadap kinerja dapat dilihat dari besarnya Adjusted $R$ Square sebesar 0,689 atau 68,90\% artinya kontribusi seluruh variabel $X$ secara serentak terhadap variabel $Y$ sebesar $68,90 \%$, Sisanya $31,10 \%$ dipengaruhi oleh variabel bebas lainnya yang tidak termasuk dalam penelitian ini, seperti motivasi, pengawasan dan kecakapan dan lain-lain yang mempengaruhi kinerja. 
Tabel 6. Rekapitulasi hasil perhitungan regresi.

\begin{tabular}{|c|c|c|c|c|c|c|}
\hline \multicolumn{2}{|r|}{ Model } & Sum of Squares & df & Mean square & $\mathrm{F}$ & Sig \\
\hline \multicolumn{2}{|c|}{$\begin{array}{ll}1 & \text { Regression } \\
& \text { Residual } \\
& \text { Total }\end{array}$} & $\begin{array}{r}20.928 \\
8.103 \\
29.031\end{array}$ & $\begin{array}{r}3 \\
26 \\
29\end{array}$ & $\begin{array}{r}6.976 \\
.312\end{array}$ & 22,383 & $.000^{\mathrm{a}}$ \\
\hline \multicolumn{2}{|c|}{ Model } & $\mathrm{R}$ & R Square & $\begin{array}{l}\text { Adjusted R } \\
\text { Square }\end{array}$ & \multicolumn{2}{|c|}{$\begin{array}{l}\text { Std Error of The } \\
\text { Estimate }\end{array}$} \\
\hline \multicolumn{2}{|l|}{1} & $.849^{a}$ & .721 & .689 & \multicolumn{2}{|c|}{.558268345} \\
\hline \multirow{2}{*}{\multicolumn{2}{|c|}{ Model }} & $\begin{array}{l}\text { Unstandardized } \\
\text { Coefficients }\end{array}$ & $\begin{array}{l}\text { Standardizet } \\
\text { Coefficients }\end{array}$ & $\mathrm{t}$ & \multicolumn{2}{|c|}{ Sig } \\
\hline & & B & Std Error & Beta & & \\
\hline \multicolumn{2}{|c|}{ 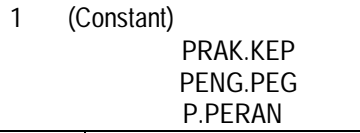 } & $\begin{array}{r}6,668 \mathrm{E}-04 \\
.393 \\
.469 \\
.117 \\
\end{array}$ & $\begin{array}{l}.102 \\
.136 \\
.155 \\
.173 \\
\end{array}$ & $\begin{array}{l}.393 \\
.469 \\
.117\end{array}$ & $\begin{array}{r}.007 \\
2.898 \\
3.020 \\
.678 \\
\end{array}$ & $\begin{array}{l}.995 \\
.008 \\
.006 \\
.504 \\
\end{array}$ \\
\hline No. & \multicolumn{2}{|l|}{ Variabel } & \multicolumn{2}{|c|}{ r Parsial } & \multicolumn{2}{|c|}{$\mathrm{r}^{2}$} \\
\hline 1 & \multicolumn{2}{|l|}{ Praktek Kepemimpinan } & \multicolumn{2}{|c|}{0,494} & \multicolumn{2}{|c|}{0,2440} \\
\hline 2 & \multicolumn{2}{|l|}{ Pengembangan Pegawai } & \multicolumn{2}{|c|}{0,510} & \multicolumn{2}{|c|}{0,2601} \\
\hline 3 & \multicolumn{2}{|l|}{ Persepsi Peran } & \multicolumn{2}{|c|}{0,132} & \multicolumn{2}{|c|}{0,0174} \\
\hline
\end{tabular}

Sumber data: hasil olahan data primer.

Untuk melihat keeratan hubungan atau korelasi antara variabel praktek kepemimpinan, pengembangan pegawai dan persepsi peran terhadap kinerja ditentukan oleh angka multiple regression sebesar 0,849 atau 84,90\%. Ternyata relatif cukup besar menunjukkan demikian eratnya hubungan seluruh variabel bebas $X$ terhadap variabel terikat $Y$.

\section{Uji t}

Untuk mengetahui pengaruh masing-masing variabel secara parsial digunakan uji t, seperti terdapat pada Tabel 6, terlihat bahwa koefisien regresi praktek kepemimpinan sebesar 0,393, pengembangan pegawai sebesar 0,469 dan persepsi peran 0,117 . Hal ini menunjukkan hubungan positif atau searah dengan kinerja penyidik PPNS HKI. Artinya apabila faktor-faktor praktek kepemimpinan, pegembangan pegawai dan persepsi peran secara parsial meningkat akan menyebabkan kinerja juga meningkat.

Untuk mengetahui besarnya pengaruh variabel praktek kepemimpinan secara parsial terhadap kinerja Penyidik PPNS HKI dilihat dari probabilitas sebesar $0,008<0,05$ atau $t$ hitung 2,898 $>t$ tabel sebesar 1,697. Artinya praktek kepemimpinan secara parsial berpengaruh signifikan terhadap kinerja penyidik PPNS $\mathrm{HKI}$, besarnya pengaruh variabel pengembangan pegawai secara parsial terhadap kinerja Penyidik PPNS HKI dilihat dari probabilitas sebesar 0,006 $<0,05$ atau t hitung $3,020>t$ tabel sebesar 1,697. Artinya pengembangan pegawai secara parsial 
berpengaruh signifikan terhadap kinerja penyidik PPNS HKI, dan besarnya pengaruh variabel persepsi peran secara parsial terhadap kinerja Penyidik PPNS HKI dapat dilihat dari probabilitas sebesar 0,504 $>0,05$ atau t hitung 0,678 $<\mathrm{t}$ tabel sebesar 1,697. Artinya persepsi peran secara parsial berpengaruh tidak signifikan terhadap kinerja penyidik PPNS HKI.

Selanjutnya untuk mengetahui besarnya kontribusi secara parsial terhadap masing-masing variabel dilakukan dengan melihat $r$ parsial coefficient yang hasilnya dikuadratkan $\left(\mathrm{r}^{2}\right)$ sehingga diperoleh hasil sebagaimana terdapat pada Tabel 6, terlihat bahwa besarnya kontribusi $(X)$ secara parsial terhadap variabel terikat kinerja (Y) masing-masing sebesar 0,2440 atau $24,40 \%$ untuk variabel praktek kepemimpinan, sebesar 0,2601 atau $26,01 \%$ untuk variabel pengembangan pegawai, sebesar 0,0174 atau 1,74 \% untuk variabel persepsi peran.

Dengan demikian, diantara ketiga variabel yang dominan memberikan kontribusi terhadap kinerja Penyidik PPNS HKI Kantor Wilayah Departemen Hukum dan HAM Provinsi se-Sumatera adalah variabel Pengembangan Pegawai sebesar $26,01 \%$. Hal ini menunjukkan bahwa hipotesis kedua juga diterima.

\section{Uji Ekonometrika Uji Multikolinearitas}

Untuk mengetahui adanya gejala multikolinearitas dapat dilakukan dengan menguji koefisien korelasi parsial terhadap variabel-variabel bebas melalui matrik korelasi dan bila korelasinya signifikan (VIF $\geq 10$ ) maka antar variabel bebas tersebut terjadi multikolinearitas, seperti tergambar dalam Tabel 7 berikut ini:

Tabel 7. Uji Koofisien korelasi parsial terhadap masing-masing variabel bebas

\begin{tabular}{|c|c|c|c|c|c|c|}
\hline & \multirow{2}{*}{ Model } & \multicolumn{3}{|c|}{ Correlations } & \multicolumn{2}{|c|}{ Collinearity Statistics } \\
\hline & & Zero-order & Partial & Part & Telerance & VIF \\
\hline 1 & & $\begin{array}{l}.712 \\
.760 \\
.718\end{array}$ & $\begin{array}{l}.494 \\
.510 \\
.132\end{array}$ & $\begin{array}{l}.300 \\
.313 \\
.070\end{array}$ & $\begin{array}{l}.583 \\
.445 \\
.358\end{array}$ & $\begin{array}{l}1.715 \\
2.246 \\
2.791\end{array}$ \\
\hline \multirow[b]{2}{*}{ Model } & & Change St & & & & \multirow{2}{*}{$\begin{array}{l}\text { Durbin- } \\
\text { Watson }\end{array}$} \\
\hline & R Square Change & F Change & Df 1 & Df 2 & $\begin{array}{c}\text { Sig F } \\
\text { Change }\end{array}$ & \\
\hline 1 & .721 & 22.383 & 3 & 26 & .000 & 1,730 \\
\hline
\end{tabular}

Sumber data: hasil olahan data primer.

Dari hasil perhitungan matrik korelasi diketahui bahwa korelasi antara variabel Praktek Kepemimpinan (X1) dengan VIF sebesar 1,715 < 10 berarti tidak terjadi Multikolinearitas, variabel Pengembangan Pegawai (X2) dengan VIF sebesar 2,246 < 10 berarti tidak terjadi multikolinearitas, dan variabel Persepsi Peran (X3) dengan VIF sebesar 2,791 < 10 berarti tidak terjadi multikolinearitas. Artinya antara variabel bebas tersebut tidak saling berkorelasi. 


\section{Uji Heteroskedastisitas}

Pengujian terhadap heteroskedastisitas dilakukan dengan mempergunakan metode Sperman rank correlation. Hasil perhitungannya dengan rincian sebagai berikut:

- Residu dan $\mathrm{X} 1=0,800$

- Residu dan $\mathrm{X} 2=0,816$

- Residu dan $X 3=0,702$

Nilai korelasi Spearman antara Residu dan X1 0,800 < nilai kritis 1,697 maka tidak terjadi heteroskedastisitas, dan nilai korelasi Spearman antara residu dan X2 0,816 < nilai kritis 1,697 maka tidak terjadi heteroskedastisitas, serta nilai korelasi Spearman antara Residu dan X3 0,702 < nilai kritis 1,697 maka tidak terjadi heteroskedastisitas.

\section{Uji Otokorelasi}

Dari hasil perhitungan dengan menggunakan uji Durbin watson seperti pada Tabel 3 diatas, ternyata nilai DW hitung sebesar 1,730 dibandingkan dengan nilai DW tabel untuk $\mathrm{N}=30$ dan $\mathrm{k}=4$, nilai du $=1,74$ dan $\mathrm{dl}=1,14$.

Atas dasar ketentuan tersebut maka bisa dibandingkan antara nilai DW hitung dengan DW tabel sebagai berikut;

$$
\begin{aligned}
4-\mathrm{DW} & >\mathrm{du} \\
4-1,730 & >1,74 \\
2,270 & >1,74
\end{aligned}
$$

Dengan demikian tidak terdapat otokorelasi pada model regresi dalam penelitian ini.

\section{PEMBAHASAN HASIL ANALISIS}

Bila diperhatikan hasil jawaban responden terlihat bahwa dalam pelaksanaan praktek kepemimpinan kurang perhatian terhadap penegakan hukum di bidang HKI, hal ini disebabkan karena (1) kurangnya pengawasan pimpinan terhadap pelaksanaan tugas penyidik PPNS HKI di lapangan, sehingga penanganan perkara tidak sampai pada proses penyidikan sedangkan tugas Penyidik PPNS HKI sangat rentan dengan penyimpangan perkara, (2) tidak adanya kompensasi terhadap hasil penyidikan oleh Penyidik PPNS HKI yang mengungkap perkara-perkara tindak pidana HKI dalam bentuk penghargaan, sedangkan Penyidik PPNS HKI melaksanakan tugas Penyidikan dalam kurun waktu $1 \times 24$ jam, sehingga terjadi penurunan kinerja, (3) kurangnya keberanian Pimpinan memberikan dukungan atas tindakan hukum oleh Penyidik PPNS HKI terhadap adanya dugaan pelanggaran dibidang HKI, hal ini disebabkan karena rata-rata Pimpinan tidak memiliki basic sebagai Penyidik, (4) rata-rata Pimpinan adalah pejabat yang akan memasuki masa pensiun, sehingga kurang respon terhadap pelaksanaan tugas-tugas yang beresiko.

Berdasarkan hasil perhitungan statistik ditemukan bahwa pengembangan pegawai berpengaruh dominan terhadap kinerja Penyidik PPNS HKI, hal ini disebabkan karena pengembangan pegawai melalui DIKLAT merupakan indikator 
penting guna membentuk tenaga Penyidik yang handal dan terampil dalam melaksanakan tugas penyidikan dan untuk dapat diangkat sebagai tenaga Penyidik PPNS HKI diperlukan persyaratan pendidikan dan latihan khusus karena mereka merupakan salah satu unsur penegak hukum di bidang penyidikan perkara pidana khusus meliputi perkara hak cipta, hak merek, hak paten, rahasia dagang, desain prototip, desain industri dan desain tata letak sirkuit terpadu.

Dari 30 orang responden rata-rata adalah pemegang jabatan rangkap sebagai Penyidik PPNS dan Pejabat Struktural eselon III dan II yang lebih banyak melaksanakan tugas sebagai penentu kebijakan di ruangan bukan di lapangan, sedangkan tugas Penyidik PPNS HKI lebih banyak di lapangan. Tingkat pendidikan respondenpun mayoritas adalah berpendidikan Strata 1 (S1) sejumlah 21 orang, Diploma 3 (D3) sejumlah 1 orang dan Pascasarjana (S2) sejumlah 8 orang.

Persepsi peran dalam hasil penelitian ini berpengaruh tidak signifikan terhadap kinerja Penyidik PPNS HKI karena berdasarkan fakta yang ada masingmasing Penyidik PPNS HKI memiliki motif tersendiri dalam mempersepsikan suatu masalah yang dihadapi dan berbeda sesuai dengan perilaku individu yang mereka miliki, sehingga dalam menjalankan perannya akan dipengaruhi oleh perilakunya sendiri. Untuk itu diperlukan aturan yang tegas bahwa Penyidik PPNS HKI adalah pejabat Fungsional dan tidak merangkap jabatan struktural, perlu dukungan dana, sarana dan prasarana yang memadai guna menunjang pelaksanaan tugas penyidikan di lapangan. Di sisi lain kuatnya intervensi Penyidik POLRI terhadap pelaksanaan Penyidikan oleh Penyidik PPNS HKI di masing-masing Kantor Wilayah Propinsi, sedangkan Penyidik PPNS HKI disebutkan memiliki Otonomi dalam Undang-Undang turut pula mempengaruhi kinerja penyidik PPNS HKI. Ada baiknya Penyidik POLRI berperan sebagai Koordinator Pengawas saja.

\section{KESIMPULAN DAN SARAN}

\section{Kesimpulan}

1. Faktor-faktor praktek kepemimpinan, pengembangan pegawai dan persepsi peran berpengaruh signifikan terhadap kinerja penyidik PPNS HKI Kantor Wilayah Departemen hukum dan HAM Provinsi se-Sumatera diterima. Hal ini terbukti dari hasil perhitungan statistik yang menunjukkan bahwa $F$ hitung sebesar 22,383 $>F$ tabel sebesar 2,92 atau probabilitas $F$ 0,000 $<0,05$.

2. Faktor pengembangan pegawai berpengaruh dominan terhadap kinerja Penyidik PPNS HKI Kantor Wilayah Departemen hukum dan HAM Provinsi se-Sumatera. $\mathrm{Hal}$ ini terbukti dari hasil perhitungan statistik yang menunjukkan bahwa koefisien $\mathrm{r}^{2}$ pengembangan pegawai sebesar $26,01 \%$ lebih besar dari persepsi peran sebesar $1,74 \%$ dan lebih besar pula dari koefisien $r^{2}$ praktek kepemimpinan sebesar $24,40 \%$. 
Agustiar, Shofia Amin \& Edward, Pengaruh Praktek Kepemimpinan ...

Saran

1. Karena faktor-faktor praktek kepemimpinan, pengembangan pegawai dan persepsi peran terbukti berpengaruh signifikan terhadap kinerja penyidik PPNS HKI, maka perlu pemberian kompensasi kepada setiap penyidik yang berhasil mengungkap perkara berupa penghargaan kenaikan pangkat pilihan atau dipromosikan pada jabatan yang lebih baik bila mereka memiliki tingkat keberhasilan kerja yang tinggi.

2. Mengingat Penyidik PPNS HKI memiliki hak otonom dalam melakukan penyidikan, maka perlu perhatian dan pengawasan pimpinan terhadap tindakan penyidik PPNS HKI, karena masing-masing Penyidik akan memiliki perbedaan persepsi terhadap perkara yang sama dalam memandang perkara yang ditangani mereka masing-masing. Perlu pula ditingkatkan koordinasi antar penyidik guna menyatukan persepsi agar Penyidik PPNS HKI tersebut tidak memainkan peran berdasarkan persepsi masing-masing dalam melakukan penyidikan.

3. Dari hasil perhitungan statistik ternyata variabel pengembangan pegawai berpengaruh dominan terhadap kinerja Penyidik PPNS HKI, maka perlu dilakukan peningkatan Diklat untuk mempersiapkan calon penyidik PPNS HKI guna pemerataan penempatan dan pengganti penyidik yang akan memasuki masa pensiun di masa mendatang pada masing-masing Kantor Wilayah Departemen Hukum dan HAM Provinsi se-Sumatera.

\section{DAFTAR PUSTAKA}

Albanese, Robert, (1978). Managing: Toward Accountability for Performance. Richard D. Irwin, Inc., Homewood, Illinois.

Anthony, William P., Pamela L. Parrewe, and K. Michele Kacmar, (1996). Strategic Human Resource Management, The Dryden Press, Harcourt Brace College Publishers, USA.

Achmad S Ruky, (2004), Sistem Manajemen Kinerja. Penerbit, PT, Gramedia Pustaka Utama, Jakarta.

Cook, Curtis W, and Hunsaker L, Phillip, (2001). Management and Organizational Behavior, Third Edition, Mc Graw- Hill, Irwin, Boston Burr Ridge, New York San Francisco.

Kouzes, James M and Barry Z. Posner, (1987). The Leadership Challenge: How to Get Extraordinary Things Done in Organizations, Jossey-Bass-Publishers, Sanfrancisco, oxford, 1991.

McCloy, Robert A., John P. Campbell, and Robert Cudeck, (1994). "A Confirmatory Test of a Model of Performance Determinants". Journal of Applied Psychology, Vol. 78, No. 4, pp.493-505. 
Milkovich, George T. and John W.Boudreau, (1991). Human Resource Management. $6^{\text {th }}$ Ed. Richard D. Irwin., Inc., U.S.A

Mitchel, Terence L, (1985). People in Organizations: An Introduction to Organizational Behavior. $2^{\text {nd }}$ Ed. McGraw-Hill Book Co., Singapore.

Mulyadi dan Setyawan, Johni, (1999). Sistem Perencanaan Dan Pengendalian Manajemen, edisi ke.1, Penerbit, Aditya Media, Yogyakarta.

Mangkunegara, Anwar Prabu, (2002). Manajemen Sumber Daya Manusia Perusahaan, PT. Remaja Rosdakarya, Bandung.

Mahmudi, (2005). Manajemen Kinerja Sektor Publik, MaUPP, Akademi Manajemen Perusahaan YKPN, Yogyakarta

Rivai, Veithzal, (2004). Manajemen Sumber Daya Manusia untuk Perusahaan, Dari Teori ke Praktik, PT, Raja Grafindo Persada, Jakarta.

Shoemaker, E Mary, (1999). Leadership Practices in Sales Managers Associated with the Self-Efficacy, Role Clarity, and Job Satisfaction of Individual Industrial Salespeople, Jurnal of personal Selling \& Sales Management, Volume XIX, Number 4, (Fall 1999, Pages 1-19).

Sudarmayanti, (2001). Sumber Daya Manusia dan Produktivitas Kerja, cetakan ke II, Penerbit, Mandar Maju, Bandung. 